sólidas amistades. Cuantos tuvieron el privilegio de conocerla y de trabajar a su lado alaban su abnegación, su perseverancia, su entusiasmo, su sencillez y su valentía. Todos guardarán un cariñoso y agradecido recuerdo de esta gran señora.

\title{
Fallecimiento del señor François de Reynold
}

El CICR se ha enterado con profundo pesar de la defunción del señor François de Reynold, ex jefe del Servicio de Protocolo, quien falleció el 11 de diciembre de 1984, a los ochenta y dos años de edad.

El señor de Reynold, licenciado en Derecho por la Universidad de Friburgo, ingresó, el 1 de abril de 1943, en el servicio italiano de la Agencia Central de prisioneros de guerra. En enero de 1945, fue transferido al Servicio de Enlace del CICR, que más tarde se convirtió en Servicio de Enlace y de Protocolo.

Nombrado jefe de este Servicio, que bajo su dirección alcanzó un auge considerable, el señor de Reynold contribuyó en gran medida al desarrollo de las relaciones del CICR con la Oficina Europea de las Naciones Unidas y sus organismos especializados, así como con las organizaciones no gubernamentales que acababan de crearse y empezaban a establecerse en Ginebra. Asimismo, representó al CICR en numerosas conferencias internacionales. En 1962, fue enviado a África occidental en misión ante varias Sociedades Nacionales en vías de formación.

El señor François de Reynold, muy conocido en los círculos internacionales por su cortesía y amabilidad, puso al servicio del CICR sus excepcionales dotes para entablar contactos a todos los niveles. Poco a poco estableció una red de relaciones que fueron de gran utilidad para el CICR en sus actividades humanitarias. Por todo ello, el Comité recordará siempre con agradecimiento los servicios que le ha prestado.

\section{Adhesión de la República Rwandesa a los Protocolos}

La República Rwandesa depositó, el 19 de noviembre de 1984, ante el Gobierno suizo, el correspondiente instrumento de adhesión a los Protocolos adicionales I y II del 8 de junio de 1977. 